G260 IDENTIFICATION OF THE HEALTH BURDEN FOR STREET
CHILDREN AND SERVICE PROVISION AVAILABLE IN
KISUMU, KENYA THROUGH FOCUS GROUP
DISCUSSIONS AND SEMI-STRUCTURED INTERVIEWS

B Eder. School of Social and Community Medicine, University of Bristol, Bristol, UK

10.1136/archdischild-2018-rcpch.253

Aims The numbers of children living 'on' or 'of' the street, Street Children and Youth (SCY), could be as high as 150 million. SCY are a particularly vulnerable and under-researched group who face unique challenges. This research uses qualitative methodology to build on current research with SCY In Kenya. It aimed to provide an opportunity for these children to share their experiences and make recommendations for how their health may be improved.

Methods Males aged between 10 and 19 accessing Hope for Victoria Children, HOVIC's (a non-governmental organisation (NGO) working in Kisumu, Kenya) night shelter or 'drop in' programme were eligible for inclusion. Children were invited to take part through a 'Baraza', a traditional community meeting and their Comprehension of Assent given in Swahili. Focus group discussions (FGDs) and semi-structured interviews were conducted, using a Guide of Thematic Topics, transcribed verbatim and thematic analysis carried out. Ethical approval was given by the University of Bristol Health Sciences Ethics Committee. Approval was given from HOVIC and Child.org (the respective NGO partners) and the District Children's Officer for Kisumu County.

Results A total of 37 SCY, all male, aged between 10 and 17 were invited to take part, including 'shelter' and 'drop-in' boys. Three FGDs and six semi-structured interviews with boys as well as four interviews with HOVIC staff were conducted. A total of five key themes were identified. What makes street children vulnerable included the reasons children came to the street, the physical environment and abuse. Substance use, mental health, sexual and reproductive health, unintentional injuries and violence made up The Health Burden of SCY. Health Services were concentrated at shelter's, similar to and including HOVIC and hospitals. Barriers to Healthcare included cost and discrimination. Suggestions were made around Improving the Health of Street Children through centres, hospitals and Government implementation of policy.

Conclusion The experiences, stories and feelings shared by SCY highlighted the key challenges they face on a daily basis. By lending a voice to SCY, we hope this research will make a valuable contribution in implementing policy that meets the needs of this vulnerable population.

\section{G261 NEONATAL OUTCOMES OF FEMALE GENITAL MUTILATION/CUTTING (FGM/C) IN THE GAMBIA: RESULTS FROM A MULTICENTRE PROSPECTIVE OBSERVATIONAL STUDY}

${ }^{1}$ AJ Armitage, ${ }^{2} \mathrm{M}$ Bittaye, ${ }^{3} \mathrm{~S}$ Agbala, ${ }^{4} \mathrm{P}$ Idoko. ${ }^{1}$ Institute of Child Health, University College London, London, UK; ${ }^{2}$ Medical Research Council Unit, Banjul, The Gambia; ${ }^{3}$ London School of Hygiene and Tropical Medicine, London, UK; ${ }^{4}$ Edward Francis Small Teaching Hospital, Banjul, The Gambia

\subsection{6/archdischild-2018-rcpch.254}

Aims Prevalence of Female Genital Mutilation/Cutting (FGM/ C) among women in The Gambia is $76.3 \%$. FGM/C was banned in 2015, but there is fear that it may be driven underground. This study aimed to provide national data on healthcare outcomes (previously lacking) to support advocacy and health education.

Methods A multicentre prospective observational study carried out across 4 healthcare facilities in the Gambia between May and September 2016.

Inclusion criteria: Consenting women aged 18 and over presenting in early labour (singleton foetus) with or without $\mathrm{FGM} / \mathrm{C}$

Data collection: Demographics, type of FGM/C (WHO classification) and outcomes of labour.

Neonatal outcomes: Perinatal death, neonatal resuscitation, low-birth-weight (table 1 and 2).

Results 1569 women were recruited. Mean age was 26.5 and parity 2.1. 77\% had FGM/C.

\begin{tabular}{llll}
\multicolumn{2}{l}{ Abstract G261 Table 1 } & \multicolumn{2}{l}{ Risk of perinatal death } \\
\hline FGM/C & $\begin{array}{l}\text { Cases/ } \\
\text { population }\end{array}$ & Percentage & $\begin{array}{l}\text { Adjusted relative risk }(95 \% \text { CI) } \\
*\end{array}$ \\
\hline None & $7 / 361$ & 1.9 & 1.0 \\
Type I & $13 / 372$ & 3.5 & $1.9(0.7-4.6)$ \\
Type II & $33 / 704$ & 4.7 & $2.5(1.1-5.7)$ \\
Type III/ & $3 / 132$ & 2.3 & $1.3(0.3-5.1)$ \\
IV & & & \\
\hline${ }^{*} \mathrm{p}=0.11$ & & &
\end{tabular}

\begin{tabular}{|c|c|c|c|}
\hline $\mathrm{FGM} / \mathrm{C}$ & $\begin{array}{l}\text { Cases/ } \\
\text { population }\end{array}$ & Percentage & $\begin{array}{l}\text { Adjusted relative risk }(95 \% \mathrm{Cl}) \\
\text { * }\end{array}$ \\
\hline None & $31 / 361$ & 8.6 & 1.0 \\
\hline Type I & $50 / 372$ & 13.4 & $1.9(1.2-3.2)$ \\
\hline Type II & $121 / 704$ & 17.2 & $2.5(1.6-4.0)$ \\
\hline $\begin{array}{l}\text { Type III/ } \\
\text { IV }\end{array}$ & $38 / 132$ & 28.8 & $3.9(2.4-6.5)$ \\
\hline
\end{tabular}

There was no association between FGM/C and low-birthweight babies observed in this study.

Conclusion A statistically significant increased risk of perinatal death was observed with type II FGM/C. The study may be underpowered to demonstrate increased risk across all types of FGM/C. Increased risk of need for neonatal resuscitation was observed in all forms of FGM/C. These results are in keeping with those from other African countries and, it is hoped, will be useful in the advocacy and sensitisation needed to end this practice.

\section{G262(P) THE MANAGEMENT OF MODERATE ACUTE MALNUTRITION IN CHILDREN AGED 6-59 MONTHS: A SYSTEMATIC REVIEW AND META-ANALYSIS}

${ }^{1}$ IG Gluning, ${ }^{2} \mathrm{NR}$ Rollins, ${ }^{1} \mathrm{CO}$ Opondo. 'Nutrition for Global Health, London School of Hygiene and Tropical Medicine, London, UK; ${ }^{2}$ Maternal, Newborn, Child and Adolescent Health, World Heath Organisation, Geneva, Switzerland

\subsection{6/archdischild-2018-rcpch.255}

Background Acute malnutrition is a leading cause of morbidity and mortality in children aged under five years, especially in 